\title{
Comparative Study on Paths of College Students' Ideological and Political Education as well as College Students' Ideal and Faith Education from the Perspective of New Media
}

\author{
Chen Shengle \\ Ideological and Political Education, China Ji Liang University \\ Hangzhou, China
}

\begin{abstract}
Through a comprehensive comparison of the research ideas of college students' ideological and political education under two kinds of new media, this paper makes a comparative study on the path of college students' ideological and political education as well as the path of college students' ideals and beliefs from the perspective of new media, and explores the new media horizon. From the perspective of new media, the path of ideological and political education as well as the path of ideals and beliefs of college students analyze the problems of path dependence, path misplacement and path ambiguity in the work of ideological and political education as well as ideal and belief education, and analyze the causes of these two problems. Finally, under the background of new media, we should use comparative research to deeply grasp the research status of college students' ideological and political education as well as ideal and belief education, and explore the challenges and opportunities faced by college students' ideological and belief education in the context of new media path.
\end{abstract}

Keywords-new media; college students; ideological and political education; comparative study

\section{INTRODUCTION}

This paper starts with the comparative study of ideological and political education and ideal and belief education from the perspective of new media, expounds the value of ideological and political education methods in the perspective of new media, and analyzes the shortcomings of new media ideological and political education methods in new media methods. At the same time, it briefly introduces the ideological and political education methods in the new media era, analyzes the advantages and disadvantages of them, and combines the characteristics of the new media era on how to innovate the traditional ideological and political education methods, and puts forward some development plans to play the value of traditional ideological and political education.

\section{RESEARCH METHODS ON THE PATH OF COLlEGE} STUDENTS' IDEOLOGICAL AND POLITICAL EDUCATION FROM THE PERSPECTIVE OF NEW MEDIA

First of all, it is a dialectical materialism and historical materialism. The process of scientific research is an effort to correctly change the world and the world. Dialectical materialism is something we can use. At the same time, historical materialism has opened up a vast new field of science for our understanding.

Second, it is a comparative study. The comparative study is the degree of similarity and difference between the subjects studied, followed by the study of general methods and special laws.

Specifically, for the research of this subject, traditional education faces a new media environment. Educators need to encourage, balance and actively adapt to the teaching mode under the background of traditional education in the context of new media. It is necessary to educate students with ideals and beliefs. Compare new situations and new ideas.

Again, historical logic and unified research methods. The historical development process includes a historical development process that reflects the understanding of objective reality and the historical development process of objective reality. Lenin pointed out that "a few people have excellent spiritual qualities, but the results of history are determined by the masses." The unity of logic and history Focus on history. You can make some independent "corrections" within certain conditions and scopes, rather than absolutely pursuing historical logic. However, in terms of the order, hierarchy, and relationship of logical categories, it must conform to the history of human cognition and scientific cognition. College ideological education is an effective way to study this proposition. Therefore, no matter whether it is administered or not, it is not only the transfer of objective historical background, but also the current educational science in the context of new media has some unconventional understanding of objective historical development. Understanding the conditions of development, understanding, educators, service providers, and educators cannot be separated 
from this goal and the history of actual development in the environment. As far as the research of this topic is concerned, the new media environment faced by college students' ideal and belief education needs to be compared and weighed with the education and teaching mode under the background of traditional education, so that educators can actively adapt to the ideal and belief education of college students under the background of new media.

Finally, the theory is linked to the actual research method. The ideals and beliefs about education itself "Scientific ideals are based on scientific theories, and our ideals and beliefs are based on the supernatural foundations of people's concepts of irrational or empirical evidence." Believing is not to allow people to accumulate science. The basic theory of knowledge and the understanding of rational evidence of scientific thinking beliefs, under the background of new media, the ideal and belief education of college students - ideal education is full of challenges and opportunities, seeking the roots, in order to realize the value and significance of this theme, It is necessary to propose an effective method, approach and method.

In addition, there are research methods for questionnaires. The research on this topic is more targeted and effective, so it must be a research topic, that is, college students make the necessary distinctions between "teaching and nonclassification" according to their specific differences, and allow them to be carried out in the context of education. We can teach better according to our own abilities. For example, what is the difference between the philosophy and beliefs of college students with different family incomes and living expenses? For example, do students with different family incomes and living expenses have different philosophies and beliefs? Will the only child affect the formation of college students' ideals and beliefs? In the process of ideological and political theory courses, do students of different majors have different attitudes? What are the opinions and opinions about the propositions of "money and success" and "dedication and value"? We designed a questionnaire as a very necessary and effective research method, and conducted a large-scale survey with students as a group. In order to improve the enthusiasm and participation of students, this topic is divided into 30 basic cases, namely, ideal beliefs, educational situations, network use and new media. It forms a questionnaire about the philosophy and beliefs of college students.

\section{RESEARCH METHODS FOR EFFECTIVE PATHS OF COLLEGE STUDENTS' IDEAL AND FAITH EDUCATION IN THE BACKGROUND OF NEW MEDIA}

First, the literature review method. The document survey method is a survey method used to inspect, classify, classify, and analyze various materials. This paper takes the ideological and political education of college students as the research object, but reviews the political education literature from the perspective of new media, and analyzes the current situation of ideological and political education of college students and the theoretical background of new media perspective. Through the comprehensive analysis and induction of the main data, the research framework of the ideological and political education path of college students from the perspective of new media has been formed, which has laid a solid foundation for more specific discussion.

Second, the system analysis method. Engels said: This is a cosmic system that leads to interactions between various objects. In this system, each element produces different functions through interaction and interdependence. The overall function of the system to the external environment, as well as the overall function of the system, is not only limited by the quantity and quality of the various elements in the system, but also depends on whether the structure of the system is fully effective.

Again, compare research methods. Comparative research methods compare phenomena and theories that occur at different times and in different situations, and investigate, analyze, identify, and organize them to obtain research methods that are consistent with objective and practical conclusions. From the perspective of new media, this paper compares the ideological and political education path of college students with the path of ideological and political education of traditional college students. Through comparative analysis and combing, identify problems and propose construction plans.

Finally, research methods applied by interdisciplinary theory. The theme of ideological and political education itself is an interdisciplinary theme, so the research method of crossapplication of subject theory is adopted. From the perspective of new media, the study of the path of ideological and political education in colleges and universities can include communication, philosophy, sociology, education, psychology and ethics.

In addition, historical survey methods. The use of the media in the ideological and political education of colleges and universities has also experienced a continuous historical period. From the school newspaper, school magazine, campus radio to the application of new media today, this is a historical development process. Therefore, we should follow up on how to scientifically use new media and find effective ways to improve the effectiveness of ideological and political education for college students. By comparing past and past history, we can analyze and study the media thinking of college students in different periods.

Research methods applied by interdisciplinary theory. The subject of ideological and political education itself is an interdisciplinary subject, so this research will adopt the research method of interdisciplinary application of subject theory. The study of the path of ideological and political education in colleges and universities from the perspective of new media may involve disciplines such as communication, philosophy, sociology, education, psychology, and ethics.

Historical survey method. The use of the media in the ideological and political education of colleges and universities has also experienced a certain historical period. From the application of new media such as school newspapers, school journals and campus radio to today, it is a historical development process. Therefore, on how to scientifically use new media to find effective ways to improve the effectiveness of ideological and political education for college students, we 
should trace the source of the theory and analyze the media of different periods by examining the past history and comparing it with the past.

Based on the views of the two papers, in order to understand and explain the two research methods, firstly, the research methods of the ideological and political education path of college students from the perspective of new media include the research methods of dialectical materialism and historical materialism. In the context of new media, the research methods of the effective path of college students' ideal belief education include literature research method, historical investigation method, cross-disciplinary theory crossapplication research method, comparative research method and system analysis method.

Second, comparative studies are more widely used in these two articles. The comparative approach of college students' ideological and political education from the perspective of new media is mainly based on the fact that the new media environment facing the ideal and belief education of college students needs to be compared and balanced with the educational model in the context of traditional education, so that educators can actively adapt to the new University in the context of the media. In the context of new media, the effective way to study college students' ideal and belief education is to compare the ideological and political education path of college students with the traditional ideological and political education path of college students from the perspective of new media. Through comparative analysis and combing, problems are found and construction plans are proposed. By comparing the external environment of the new media with the traditional education model or path, I put forward my own views.

Finally, other methods, such as the combination of theory and practice and system analysis, are also included. From the perspective of new media, the research methods of college students' ideological and political education are based on the philosophical methods of dialectical materialism and historical materialism, as well as the research methods of logic and history. These methods are more textual. In the context of new media, the study of the effective path of college students' ideals and beliefs education is more innovative, but the author did not conduct in-depth explanation or in-depth research and interpretation, which is a pity.

\section{THE DIFFERENCE BETWEEN THE TWO RESEARCH IDEAS}

The research on the path of ideological and political education for college students from the perspective of new media divides the research ideas into four parts: through the definition of new media, the investigation and research on the status quo of college students' ideals and beliefs, investigation and research, and data analysis, exploring the ideals of college students urgently needed in practice The effective path and method of belief education further improve and perfect the education of college students' ideals and beliefs under the background of new media.

However, the logic of the effective path of college students' ideal and belief education in the context of new media is not clear enough. Firstly, it sorts out the relevant concepts of the ideological and political education path of college students from the perspective of new media, and clearly expounds the concept and connotation of the ideological and political education path of college students from the perspective of new media. Secondly, on the basis of clarifying the relationship between the evolution of the media and the development of the ideological and political education of college students, it expounds the inevitability and value of using the new media to carry out the ideological and political education of college students. Thirdly, under the guidance of the discipline and related discipline theory, this paper analyzes the status quo, achievements and existing problems of the new media on college students' ideological and political education, and summarizes the causes of the problems. In addition to the new media itself, it also includes some shortcomings of the educators themselves. Finally, in response to these problems, the principles and ideas for constructing the path of ideological and political education for college students are put forward. Under the guidance of ideas and principles, we strive to optimize and expand the path of ideological and political education for current college students. On the basis of the formation of the ideological and political education path of college students from the perspective of new media, it is carried out from three aspects: school material security and teacher team.

Compared with the research ideas of the two, the research on the ideological and political education path of college students is better than the new media, and the quality of the ideological and political education path under the new media perspective is more theoretically elaborated.

\section{CONCLUSION}

The author believes that the most common, simple, and popular research methods of doctoral dissertations in the field of new media are still relatively research. If you want to innovate, you need to join the cross-application research method of subject theory, and combine various disciplines to achieve greater brilliance. We should use comparative research to deeply grasp the research status of college students' ideological and political education and ideal and belief education, and explore the challenges and opportunities faced by college students' ideological and belief education in the context of new media path.

\section{REFERENCES}

[1] Yuan Lili. Research on the Effective Path of College Students' Ideal and Faith Education under the Background of New Media[D]. Hebei Normal University, 2017.

[2] Zhao Xiang. Research on the path of ideological and political education for college students under the new media[D]. China University of Mining and Technology (Beijing), 2017.

[3] Zhai Yongxin. The Status Quo and Prospect of the Research on the Effectiveness of College Students' Ideological and Political Education[J]. Journal of Knowledge, 2015

[4] Wang Jia. Research on Network Opinion Leaders in the Perspective of Ideological and Political Education [D]. Dalian University of Technology, 2013.

[5] Qiu Zhiwei. Research on College Students' Ideological Education from the Perspective of Media[D]. Hebei Normal University, 2018.

[6] Liang Guangxia. Research on the construction of mainstream ideological voice in colleges and universities from the perspective of media [D]. Beijing Jiaotong University, 2018. 